Publisher homepage: www.universepg.com, ISSN: 2663-6913 (Online) \& 2663-6905 (Print)

https://doi.org/10.34104/ajpab.019.0193043

American Journal of Pure and Applied Biosciences

Journal homepage: www.universepg.com/journal/ajpab

\title{
Effect of Plant Growth Regulator on the Growth and High Yield of Heat Tolerant Tomato Variety (Lycopersicon esculentum Mill)
}

\author{
Syed Moazzem Hossain ${ }^{1}$, Chinmoy Sarker ${ }^{2}$, and Sarif Mahmud ${ }^{3}$ \\ ${ }^{1}$ National Food Safety Consultant-Horticulture, FAO of the UN, Bangladesh; ${ }^{2}$ Department of Food Technology \& Rural \\ Industries, Bangladesh Agricultural University, Mymensingh, Bangladesh; and ${ }^{3}$ National Consultant Food Safety Analyst, \\ FAO Bangladesh. \\ *Correspondence: moazzem144@gmail.com
}

\begin{abstract}
An investigation was undertaken with a view to observing the performance of two heat-tolerant varieties of tomato under polytunnel with and without plant growth regulator application during summer-rainy season. The present study was laid out in a Randomized Completely Block Design (RCBD) with three replications. Two heat-tolerant tomato varieties Bangladesh Agriculture Research Institute (BARI) Tomato-4, and BARI Hybrid Tomato-4 with and without plant growth regulator applications were included in this experiment. The larger fruit set percentage (42.52\%) was observed from BARI Hybrid Tomato-4 which was also larger in case of pollen viability (42.75\%), figure of fruits every cluster (3.01), figure of fruits every plant (12.70), and yield every plant $(460 \mathrm{~g})$. Better yield was showed in spraying of 4-CPA at $40 \mathrm{ppm}$ concentration in respect of percent fruit set $(45.38 \%)$, figure of fruits every plant (16.45), and yield (39.39 t/ha) under high temperature condition. In integrate treatment, BARI Hybrid Tomato-4 with $40 \mathrm{ppm}$ 4-CPA performed a significant role in the figure of fruits every cluster (3.41), figure of fruits every plant (22.48), figure of fruits every plot (144.00), yield every plant $(621.68 \mathrm{~g})$, yield every plot $(15.23 \mathrm{~kg})$ and above all fruit yield $(50.57 \mathrm{t} / \mathrm{ha})$. This indicates that there is the bright scope of tomato production during summer through with and without plant yield regulator application, though application of plant growth regulator had positive impact on tomato yield.
\end{abstract}

Keywords: Heat tolerant tomato, Lycopersicon esculentum, plant growth regulator, yield, and hybrids.

\section{INTRODUCTION}

Tomato variety (Lycopersicon esculentum Mill.) is the most popular vegetables in Bangladesh which is receiving increased attention of the growers and consumers and made its position within a few of the highest cultivated vegetables. November and February are the periods when the congenial atmosphere remains for tomato farming in Bangladesh. Although tomato plants can cultivate under a broad range of climatic conditions, they are very sensitive to dry and wet cultivation conditions, the weather which superior in the summer season in Bangladesh (Ahmed, 2002). When night temperatures are lower than $10-12^{\circ} \mathrm{C}$ and day temperatures not higher than $20-22^{\circ} \mathrm{C}$, pollen

might not be viable or might not disperse freely from the pollen sacs. At night temperatures of $20-22^{\circ} \mathrm{C}$ or day temperatures of $32^{\circ} \mathrm{C}$ or above, a similar situation might arise and in some varieties, the style might be elongated and the stigma be exerted and so prevent pollination (Rylski et al., 1984; Shahen et al., 2019). Present results are in harmony with earlier reports of genotypic variations with regard to plant height by Zahedi and Ansari (2012).

Year-round tomato yield in Bangladesh is constrained by many ecological factors of which seasonality, and diverse disease problems are the two main. Fruit 
setting in tomato is reportedly interrupted at temperature above $26 / 20{ }^{\circ} \mathrm{C}$ day/night respectively and often completely arrested above 38/27 ${ }^{\circ} \mathrm{C}$ day/night (Stevens and Rudich, 1978). Very recently BARI has strengthened the program for year-round tomato variety development and already succeeded to develop some heat-tolerant $\mathrm{OP}$ and $\mathrm{F}_{1}$ tomato varieties (Anonymous, 1998) with some limitations like lower fruit set or smaller fruit size. Hybrids bred for heat tolerance might have best performance over any openpollinated varieties but should be examined under exact situation i.e. hot- humid conditions as the heattolerant genes are simply influenced by the environment (Villareal and Lai, 1979). The problem is due to highest night temperature $\left(>22^{\circ} \mathrm{C}\right)$ in high humidity which results in poor pollination and followed by low fertilization. Although the problem is resolved with the utilization of heat-tolerant varieties; these are Inadequate under diverse conditions. Application of plant yield regulators has been represented to improve fruit setting (AVRDC, 1990a).

Tomatotone (4-chlorophenoxy acetic acid) has been found to be effective in improving tomato fruit set under higher temperature conditions (Kuo et al., 1979). The culture regulator 4-chlorophenoxy acetic acid, (4-CPA) has a pivotal effect on the fruit retention of tomato as well as other horticultural crops, and thus enhancing the yield substantially (Nothmann, 1997). 4 -chlorophenoxy acetic acid is a growth regulator used in reducing pre-harvest fruit drop and resulting in an increased number of fruits and yield in tomato crops. Gibberellic acid $\left(\mathrm{GA}_{3}\right)$ is one of the most necessary growth stimulating components used in agricultural field since long ago. Under Bangladesh conditions, tomato is available in the urban market at an exorbitant price (Tk. 40 to $60 / \mathrm{kg}$ ) in the summer season. These tomatoes are coming from exotic sources mostly through unapproved channels. There is a great demand for tomato in the summer-rainy season. The Horticultural Research Center of the BARI has been taken program for the development OP and $F_{1}$ summer tomato varieties. Among these varieties, BARI Tomato-4, and BARI Hybrid Tomato4 are also common. But their fruit set percentage and size of the fruits is not appreciable. Therefore, the present study was operations were done properly taken to find out to improve the yield per unit area and improve the size of the fruit; an effort was undertaken to study the influence of 4-CPA and GA3.

\section{MATERIALS AND METHODS}

The field experiment was carried on at the Horticultural farm of BARI, Joydebpur, Gazipur during the month from May to August 2018. The study area of the site is at $24.00^{\circ} \mathrm{N}$ latitude and $90.25^{\circ} \mathrm{E}$ longitude at an elevation of 8.4 meters from the sea level (Anonymous, 1995). The soil of the study plot was in Salna series of Shallow Red Brown Terrace Soil (Shaheed, 1984). Two varieties of tomato, BARI Tomato-4, and BARI Hybrid Tomato-4, mostly with different degree of heat tolerance made by the Olericulture Division of HRC, BARI, and Bangladesh were collected for the study in 2018. The two-heat tolerant tomato BARI Tomato-4 and BARI Hybrid Tomato-4 were grown in summer seasons of 2018. The experiment was laid out in two factorials RCBD with 3 replications -

Factor A: Variety (two)

i. BARI Tomato- $4\left(\mathrm{~V}_{1}\right)$

ii. BARI Hybrid Tomato- $4\left(\mathrm{~V}_{2}\right)$

Factor B: Plant Growth Regulator (PGR) Concentration (five)

i. Treatment $\left(\mathrm{T}_{0}\right)$ : Control/No PGR

ii. Treatment $\left(\mathrm{T}_{1}\right)$ : 4- CPA $20 \mathrm{ppm}$

iii. Treatment $\left(\mathrm{T}_{2}\right)$ : 4-CPA $40 \mathrm{ppm}$

iv. Treatment $\left(\mathrm{T}_{3}\right): \mathrm{GA}_{3} 10 \mathrm{ppm}$

v. Treatment $\left(\mathrm{T}_{4}\right): \mathrm{GA}_{3} 20 \mathrm{ppm}$

The study was laid out in a two-factor RCBD Factorial with three replications. Two varieties of tomato were constantly allotted in each block. The unit plot size was $3.0 \mathrm{~m}$ x $1.0 \mathrm{~m}$ and the plants were spaced $60 \times 40$ $\mathrm{cm}$ on beds. Each unit plot contains double rows accommodating 12 plants of each variety. There were five tunnels in that experiment where each tunnel contained three plots. Plant growth regulator at different concentration had been sprayed to the flower of tomato. The plant yield regulators were 4Chlorophenoxy acetic acid (Tomatotone) (20 ppm and $40 \mathrm{ppm})$ a fruit setting PGR and Gibberellic acid-3 $\left(\mathrm{GA}_{3}\right)$ (10 ppm and $\left.20 \mathrm{ppm}\right)$. Data were managed from five constantly selected plants of each replication of whole treatments that separately on the following parameters in each unit plot.

Fruits per cluster and Fruit set (\%): The average value of total number of fruits in the fruited clusters was counted and was taken as fruits per cluster. The value was counted by using the following formula (1)- 


$$
\begin{aligned}
& \text { Fruit set } \%=\frac{\text { Totalnumberof fruitsof first fiveclusters }}{\text { Total number of flowers of first five cluster }} \times 100 \\
& \text { Fruit yield }\left(\frac{t}{h a}\right)=\frac{\text { Fruityieldperplot }(\mathrm{kg})}{\text { Areaofplotinsquaremeter }} \times 100
\end{aligned}
$$

Yield per hectare (ton): Each plot size was $3 \times 1 \mathrm{~m}^{2}$. Therefore, yield per hectare was counted in ton. It was measured by the following above formula (2) -

Fruit length and Fruit diameter (cm): By using a digital slide calipers fruit lengthy was measured from the neck of the fruit to the bottom of the same from ten representative fruits and their average was taken as the length of the fruit. Fruit diameter/Breadth was measured along the equatorial part of the same ten representative fruits taken for fruit length by digital slide calipers and their average was taken as the diameter of the fruit.

Total Soluble Solid (\%) (TSS): A hand Refractometer was used to record the percent of total soluble solids or Brix percentage. The value was the average of five representative fully ripened fruits.

Statistical analysis: The data in respect of growth yield, and yield contributing features were statistically evaluated to find out the statistical significance of study results by using MSTAT-C a computer-based program. The means for all the treatments were calculated, and analyses of variance for all the characters were examined by "F" test. Treatment means were estimated by Duncan's Multiple Range
Test (DMRT), and coefficient of variation (CV \%) were also estimated as instructed by Gomez and Gomez (1984).

\section{RESULTS AND DISCUSSION}

The result of the experiment along with interpretation and discussion in relation to the different tomato varieties and plant yield regulators merit are illustrated in this chapter. Different yield contributing characters of tomato responded remarkably against the corresponding treatments. The effect of varieties, and plant growth regulator as well as their interaction on most of the plant characters and yield was significant, which are discussed in details chronologically as follows:

Main effects of varieties on floral characteristics of tomato Days to $50 \%$ flowering: Days required to $50 \%$ flowering of two heat-tolerant tomato lines were recorded under field conditions. There was no significant difference between the two lines, BARI Tomato- 4 and BARI Hybrid Tomato- 4 and it varied from 43.86 days 44.40 days (Table 1) where the higher (44.40 days) was found in BARI Tomato-4. High temperature probably interrupted the process of flowering (Ahmad, 2002).

Table 1: Main effects of varieties and plant yield regulators on the floral characteristics of tomato.

\begin{tabular}{|cccc|}
\hline Treatments & Days to 50\% Flowering & No off lowers/cluster & Pollen Viability (\%) \\
\hline \multicolumn{4}{|c|}{ Variety } \\
\hline $\mathrm{V} 1$ & 44.40 & $5.85^{\mathrm{b}}$ & $32.78^{\mathrm{b}}$ \\
\hline $\mathrm{V} 2$ & 43.86 & $7.02^{\mathrm{a}}$ & $42.75^{\mathrm{a}}$ \\
\hline Level of Significance & $\mathrm{NS}$ & $* *$ \\
\hline \multicolumn{4}{c|}{} \\
\hline $\mathrm{T}_{0}$ & Plant growth regulator & 34.78 \\
\hline $\mathrm{T}_{1}$ & 45.76 & 5.79 & 34.77 \\
\hline $\mathrm{T}_{2}$ & 45.83 & 5.74 & 34.77 \\
\hline $\mathrm{T}_{3}$ & 44.83 & 5.80 & 34.78 \\
\hline $\mathrm{T}_{4}$ & 43.76 & 5.77 & 34.77 \\
\hline Level of Significance & 44.76 & 5.80 & $\mathrm{NS}$ \\
\hline $\mathrm{CV} \%$ & $\mathrm{NS}$ & $\mathrm{NS}$ & 6.39 \\
\hline
\end{tabular}

Note: Means in a column followed by the same letters or without letter are not significantly different at $1 \%$ and $5 \%$ level by DMRT; where **, Significant at $1 \%$ level; NS-Non-Significant. 
Number of flowers per cluster: Important variation was perceived between two varieties in case of the number of flowers per cluster (Table 1). The maximum (7.02) flowers per cluster were produced by BARI Hybrid Tomato-4 which was about $20 \%$ more than BARI Tomato-4 (5.85). Stevens (1979) reported that the extent of decreased flower number depends on cultivars. The finding supported to the variation between two lines in the present investigation.

Viable pollen grain: The most important character for bearing fruits was pollen viability. Percent viable pollen grain varied significantly between the two heattolerant varieties of tomato (Table 1). BARI Tomato-4 exhibited the lower (32.78\%) viable pollen grains than BARI Hybrid Tomato-4 (42.45\%). The result indicated that both the heat-tolerant varieties have the capacity to produce a higher percentage of viable pollen grain as per carmine acetic acid viability test, gives an apparent indication of pollen viability. Bodo (1991) announced that the yield of viable pollen decreased with the increase of day temperature.

Main impacts of varieties, and plant yield regulators on plant features of tomato number of branches per plant: The figure of branches per plant did not show a significant difference between the two lines at the final harvest stage (Table 2). The figure of branches per plant slightly varied from 5.06 to 5.21. BARI Hybrid Tomato-4 (5.21) showed the lower figure of branches per plant compare to BARI Tomato-4 (5.06). Phookan et al., (1990) found that the figure of branches per plant varied from 5.00 to 10.50 in the summer season under plastic house conditions. The results of the present experiment was a little bit lower to their findings, which might be due to the difference in growing environments or the difference of varieties or both. In case of plant growth regulator, the figure of branches per plant at the final harvest was significantly affected by the treatments (Table 2). The figures of branches per plant at final harvest were statistically different and higher (7.10) figure was counted by the non-plant growth regulator treatment i.e. control, where plant growth regulator treatments gave statistically similar results which were less than non-plant growth regulator one. The highest (5.38) figure of branches per plant was found when 4-CPA applied at $40 \mathrm{ppm}$ concentration. The second highest (4.86) figure of branches per plant was observed in the spray of $\mathrm{GA}_{3}$ at $20 \mathrm{ppm}$ concentration. Application of plant growth regulator (4-CPA at $20 \mathrm{ppm}$ concentration) has a suppressive effect on vegetative growth as a whole (Ramin, 1998). So, the number of branches per plant reduced may be due to plant growth regulator application.

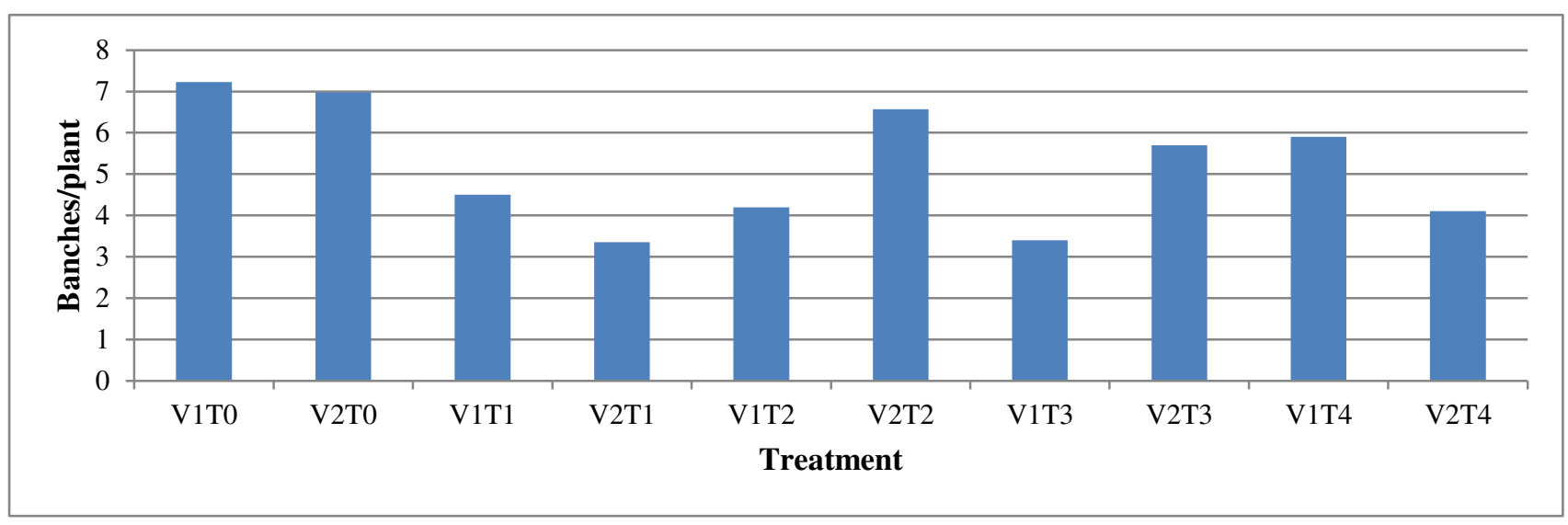

Fig 1: Combined effect of varieties and plant yield regulators on number of branches per plant.

The combined effect of varieties and different concentrations of plant growth regulator on the number of branches per plant at the final harvest is presented in Fig 1. The highest (7.23) number of branches per plant was obtained from the treatment $\mathrm{V}_{1} \mathrm{~T}_{0}$ which is significantly different from the other combinations. The lowest number of branches per plant (3.35) was given by the treatment $\mathrm{V}_{2} \mathrm{~T}_{1}$ which is statistically similar to $\mathrm{V}_{1} \mathrm{~T}_{3}(3.40), \mathrm{V}_{2} \mathrm{~T}_{4}(4.10)$, and
$\mathrm{V}_{1} \mathrm{~T}_{2}$ (4.20). The second-highest number of branches per plant was counted in $\mathrm{V}_{2} \mathrm{~T}_{0}$ (6.98) which were statistically as $\mathrm{V}_{2} \mathrm{~T}_{2}(6.57)$.

Plant height: Plant height of two varieties of summer tomato under study conditions at final harvest represented significant differences (Table 2). Plant height ranged from $95.88 \mathrm{~cm}$ to $99.80 \mathrm{~cm}$. BARI Hybrid Tomato-4 produced the taller (99.80) plants 
than BARI Tomato-4 (95.88). It was revealed that most of the hybrids of tomato performed better under field conditions in Bangladesh. Phookan et al. (1990) reported that when yield tomato in summer under plastic house conditions the plant height ranged from $46.00 \mathrm{~cm}$ to $95.00 \mathrm{~cm}$ in a study with 29 hybrids of tomato, and also manifested variations among the hybrids in plant height. In the case of plant growth regulator, the plant height at final harvest was significantly affected by the treatments (Table 2). Plant heights $(\mathrm{cm})$ at final harvest were statistically different and higher $(107.22 \mathrm{~cm})$ plant height was measured in the non-plant growth regulator treatment where plant growth regulator treatments gave the lower plant height. $\mathrm{GA}_{3}$ at $10 \mathrm{ppm}$ concentration gave the tallest $(98.99 \mathrm{~cm})$ plant height among the treatments and the shortest (91.00) plant height at the final harvest was found in 4-CPA at $20 \mathrm{ppm}$ concentration. This might be due to the suppressive impact of plant yield regulator on the vegetative part of the plant or maybe more photosynthesis supplied to the fruits as the figure of fruits increased by plant growth regulator that reduced the vegetative growth.

Table 2: Main effects of varieties, and plant yield regulators on the plant characteristics.

\begin{tabular}{|c|c|c|}
\hline Treatment & Number of branches/plants & Plant height $(\mathrm{cm})$ \\
\hline \multicolumn{3}{|c|}{ Variety } \\
\hline $\mathrm{V}_{1}$ & 5.067 & $95.88^{b}$ \\
\hline $\mathrm{V}_{2}$ & 5.215 & $99.80^{\mathrm{a}}$ \\
\hline Level of significance & NS & $*$ \\
\hline \multicolumn{3}{|c|}{ Plant growth regulator } \\
\hline $\mathrm{T}_{0}$ & $7.107^{\mathrm{a}}$ & $107.22^{a}$ \\
\hline $\mathrm{T}_{1}$ & $4.113^{c}$ & $91.00^{\mathrm{c}}$ \\
\hline $\mathrm{T}_{2}$ & $5.385^{b}$ & $94.81^{\text {be }}$ \\
\hline $\mathrm{T}_{3}$ & $4.240^{\mathrm{c}}$ & $98.99^{b}$ \\
\hline $\mathrm{T}_{4}$ & $4.860^{\text {be }}$ & $97.07^{b}$ \\
\hline Level of Significance & $* *$ & ** \\
\hline $\mathrm{CV} \%$ & 4.90 & 4.44 \\
\hline
\end{tabular}

Note: Means in a column followed by the same letters or without letter are not significantly different at $1 \%$ and 5\% level by DMRT; where** - Significant at $1 \%$ level; * - Significant at 5\% level; and NS -Non-Significant.

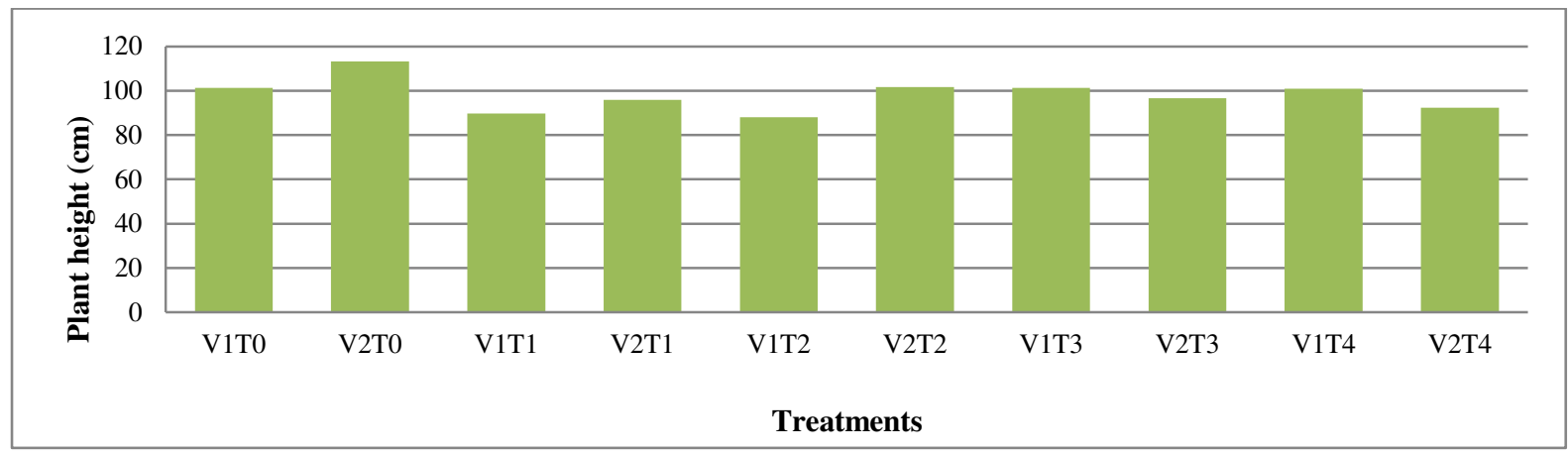

Fig 2: Combined effect of varieties and plant yield regulators on the plant height at final harvest.

Significant influence was found in the plant height due to the combined effect of tomato varieties and plant yield regulators $($ Fig 2). The highest $(113.25 \mathrm{~cm})$ plant height was measured in $\mathrm{V}_{2} \mathrm{~T}_{0}$ whereas $\mathrm{V}_{1} \mathrm{~T}_{2}$ showed the lowest $(87.95 \mathrm{~cm})$ plant height that is statistically same as $\mathrm{V}_{1} \mathrm{~T}_{1}(87.97 \mathrm{~cm})$. The second highest $(101.67$ $\mathrm{cm})$ plant was recorded from the combination of $\mathrm{V}_{2} \mathrm{~T}_{2}$ which was statistically similar to the combinations of
$\mathrm{V}_{1} \mathrm{~T}_{3}(101.33 \mathrm{~cm}), \mathrm{V}_{1} \mathrm{~T}_{0}(101.19 \mathrm{~cm}), \mathrm{V}_{1} \mathrm{~T}_{4}(100.98$ $\mathrm{cm})$ and $\mathrm{V}_{2} \mathrm{~T}_{3}(96.66 \mathrm{~cm})$.

Main impacts of varieties, and plant yield regulators on fruit features of tomato Fruit set: Important variation was observed between the varieties in terms of percent fruit set which significantly ranged from $40.46 \%$ to $42.52 \%$ (Table 
3). The higher (43.25\%) fruit set percent was found in variety BARI Hybrid Tomato-4 which was nearer to BARI Tomato - 4 (40.46\%). Baki \& Stomuel (1993) and Rama \& Kalloo (1989) reported that fruit set in the heat-tolerant hybrids of tomato ranged from 1.9 to $46.97 \%$, which is in agreement with the present findings. Significant effect due to plant development regulator application was found on percent fruit set (Table 3). The highest (45.38\%) percent fruit set was observed by the PGR treatment of 4-CPA at the rate of $40 \mathrm{ppm}$ concentration over non-PGR treatment (36.44\%). The second highest (43.33\%) percent fruit set was counted by the PGR treatment of $\mathrm{GA}_{3}$ at the rate of $10 \mathrm{ppm}$ concentration. It was evident that the combined effect between varieties and plant development regulator significantly affected the percent fruit set (Table 4). The highest $(47.50 \%)$ percent fruit set was obtained in $\mathrm{V}_{1} \mathrm{~T}_{2}$ that was statistically different with other treatment combinations. The lowest (34.93\%) percent fruit set was measured in the treatment $\mathrm{V}_{1} \mathrm{~T}_{0}$ and it was statistically similar to the treatment $\mathrm{V}_{1} \mathrm{~T}_{1}(35.59 \%)$. The second highest $(46.18 \%)$ percent fruit set was obtained by the treatment of $\mathrm{V}_{2} \mathrm{~T}_{1}$ followed by the treatment $\quad \mathrm{V}_{2} \mathrm{~T}_{3} \quad(44.46 \%), \quad \mathrm{V}_{2} \mathrm{~T}_{2} \quad(43.25 \%), \quad \mathrm{V}_{1} \mathrm{~T}_{3}$ (42.21\%), $\quad \mathrm{V}_{1} \mathrm{~T}_{4}(42.09 \%)$ that were statistically similar. Increasing fruit set by using the plant development regulator "Tomatotone" was also reported by AVRDC (1990b).

Fruit length: Fruit length of two heat-tolerant varieties differed significantly (Table 03). The maximum number of long $(4.10 \mathrm{~cm})$ fruit was measured in BARI Hybrid Tomato-4 than BARI Tomato-4 $(3.70 \mathrm{~cm})$. Ahmad (2002) found similar trends of result in an experiment of 49 varieties in summer-rainy season which ranged from 1.94 to 5.46 $\mathrm{cm}$. Fruit length $(\mathrm{cm})$ was significantly affected by the plant development regulator application which is shown in Table 3. The maximum fruit length (4.69 $\mathrm{cm})$ was measured in the PGR treatment over nonPGR treatment $(3.82 \mathrm{~cm})$. Among the plant development regulator treatments, 4-CPA at $20 \mathrm{ppm}$ concentration gave the highest $(4.69 \mathrm{~cm})$ fruit length and the lowest $(4.22 \mathrm{~cm})$ fruit length was observed from 4-CPA at $40 \mathrm{ppm}$ concentration. Cell division and cell elongation enhanced by hormone application. So, fruit length may be increased due to plant development regulator effect. It is reported that the utilization of plant development regulator (4-CPA) can be considered for increasing fruit size under hightemperature conditions (AVRDC, 2005). Fruit length (cm) was significantly influenced by the combined effect of varieties and plant development regulator applications (Table 4). The highest $(5.14 \mathrm{~cm})$ fruit length was measured from the treatment combinations of $\mathrm{V}_{1} \mathrm{~T}_{1}$ and the second-highest $(5.06 \mathrm{~cm})$ fruit length was found in $\mathrm{V}_{1} \mathrm{~T}_{3}$ among the other treatments. The shortest $(3.77 \mathrm{~cm})$ fruit length was measured in $\mathrm{V}_{1} \mathrm{~T}_{0}$ which was statistically similar to $\mathrm{V}_{2} \mathrm{~T}_{0}(3.88 \mathrm{~cm})$.

Fruit diameter: Significant variation was observed between two varieties in respect of fruit diameter which ranged from $3.57 \mathrm{~cm}$ to $4.74 \mathrm{~cm}$ (Table 3). The higher fruit diameter $(4.74 \mathrm{~cm})$ was obtained from BARI Hybrid Tomato-4 variety than BARI Tomato-4 $(3.57 \mathrm{~cm})$. There had a significant effect of plant development regulator on fruit diameter which is shown in Table 03. PGR treatment gave better results over non-PGR treatment $(3.62 \mathrm{~cm}) .4-\mathrm{CPA}$ at $20 \mathrm{ppm}$ concentration produced the highest $(4.70 \mathrm{~cm})$ fruit diameter among the others. The lowest fruit diameter was measured in the plant development regulator application of 4-CPA at $40 \mathrm{ppm}$ concentration (4.01 $\mathrm{cm})$. Fruit diameter may be increased due to an increased rate of cell division and cell elongation by plant development regulator. In the case of combined effect, the treatment $\mathrm{V}_{1} \mathrm{~T}_{1}$ gave the highest $(4.74 \mathrm{~cm})$ fruit diameter among the other treatment combinations. The second highest $(4.54 \mathrm{~cm})$ fruit diameter was measured in $\mathrm{V}_{2} \mathrm{~T}_{4}$ which was statistically similar to $\mathrm{V}_{1} \mathrm{~T}_{3}(4.47 \mathrm{~cm})$ and $\mathrm{V}_{2} \mathrm{~T}_{2}(4.39 \mathrm{~cm})$. The treatment $\mathrm{V}_{1} \mathrm{~T}_{0}$ gave the minimum $(3.59 \mathrm{~cm})$ fruit diameter among the others (Table 4).

Table 3: Main effects of varieties and plant development regulators on the fruit characteristics.

\begin{tabular}{|c|c|c|c|c|}
\hline Treatment & Fruit set (\%) & Fruit length (cm) & Fruit diameter (cm) & TSS (\%) \\
\hline \multicolumn{5}{|c|}{ Variety } \\
\hline $\mathrm{V}_{1}$ & $40.46^{\mathrm{b}}$ & $3.70^{\mathrm{b}}$ & $3.57^{\mathrm{b}}$ & $3.52^{\mathrm{b}}$ \\
\hline $\mathrm{V}_{2}$ & $42.52^{\mathrm{a}}$ & $4.10^{\mathrm{a}}$ & $4.74^{\mathrm{a}}$ & $3.97^{\mathrm{a}}$ \\
\hline Level of Significance & $*$ & $*$ & $*$ & $*$ \\
\hline \multicolumn{6}{|c}{} \\
\hline
\end{tabular}




\begin{tabular}{|c|c|c|c|c|}
\hline $\mathrm{T}_{0}$ & $36.44^{\mathrm{c}}$ & $3.82^{\mathrm{c}}$ & $3.62^{\mathrm{d}}$ & $3.82^{\mathrm{a}}$ \\
\hline $\mathrm{T}_{1}$ & $40.87^{\mathrm{b}}$ & $4.69^{\mathrm{a}}$ & $4.70^{\mathrm{a}}$ & $3.45^{\mathrm{b}}$ \\
\hline $\mathrm{T}_{2}$ & $45.38^{\mathrm{a}}$ & $4.22^{\mathrm{b}}$ & $4.01^{\mathrm{c}}$ & $3.75^{\mathrm{ab}}$ \\
\hline $\mathrm{T}_{3}$ & $43.33^{\mathrm{ab}}$ & $4.63^{\mathrm{a}}$ & $4.50^{\mathrm{b}}$ & $3.72^{\mathrm{ab}}$ \\
\hline $\mathrm{T}_{4}$ & $41.45^{\mathrm{b}}$ & $4.52^{\mathrm{ab}}$ & $4.26^{\mathrm{be}}$ & $3.96^{\mathrm{a}}$ \\
\hline Level of Significance & $* *$ & $*$ & $*$ & $*$ \\
\hline $\mathrm{CV} \%$ & 5.82 & 2.30 & 2.53 & 6.45 \\
\hline $\mathrm{hg}$ & $\mathrm{f}$ & $\mathrm{n}$ & $\mathrm{f}$ & $\mathrm{k}$ \\
\hline
\end{tabular}

Note: Means in a column followed by the same letters or without letter are not significantly different at $1 \%$ and $5 \%$ level by DMRT; where ** - Significant at $1 \%$ level; * - Significant at $5 \%$ level.

Total soluble solids (TSS \%): Significant variation was found between the fruits of two varieties of BARI Tomato- 4 and BARI Hybrid Tomato- 4in respect of TSS content (Table 3). BARI Hybrid Tomato-4 showed the highest (3.97) percent total soluble solids which were statistically similar to BARI Tomato-4 (3.52). The result was supported by the finding of Ahmed (2002) where TSS (\%) was found to vary from 3.00 to 5.50 in an experiment in the summer season. $\mathrm{GA}_{3}$ at the rate of $20 \mathrm{ppm}$ concentration (3.96) and control treatment (3.82) gave the best performance in case of TSS percentage. The lowest (3.45) TSS was measured in spraying of 4-CPA at $20 \mathrm{ppm}$ concentration (Table 3). In the case of combined effect, the highest (4.27) TSS percent was found in $\mathrm{V}_{2} \mathrm{~T}_{4}$ and $\mathrm{V}_{2} \mathrm{~T}_{0}$ (4.22) over the treatment $\mathrm{V}_{2} \mathrm{~T}_{3}$ (4.15),

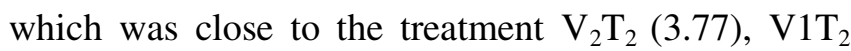
(3.72), $\mathrm{V}_{1} \mathrm{~T}_{4}$ (3.65), $\mathrm{V}_{2} \mathrm{~T}_{1},(3.45), \mathrm{V}_{1} \mathrm{~T}_{1},(3.51), \mathrm{V}_{1} \mathrm{~T}_{0}$ (3.43). $V_{1} T_{3}$ gave the lowest (3.29) TSS percent followed by the remaining combinations which gave statistically similar results (Table 4).

Table 4: Combined effect of varieties and plant development regulators on the fruit characteristics.

\begin{tabular}{|c|c|c|c|c|}
\hline Treatments & Fruit set $\mathbf{( \% )}$ & Fruit length (cm) & Fruit diameter (cm) & TSS (\%) \\
\hline $\mathrm{V}_{1} \mathrm{~T}_{0}$ & $34.93^{\mathrm{e}}$ & $3.77^{\mathrm{e}}$ & $3.59^{\mathrm{e}}$ & $3.43^{\mathrm{cd}}$ \\
\hline $\mathrm{V}_{1} \mathrm{~T}_{1}$ & $35.59^{\mathrm{e}}$ & $5.14^{\mathrm{a}}$ & $4.74^{\mathrm{a}}$ & $3.51^{\mathrm{cd}}$ \\
\hline $\mathrm{V}_{1} \mathrm{~T}_{2}$ & $47.50^{\mathrm{a}}$ & $3.99^{\mathrm{de}}$ & $3.78^{\mathrm{de}}$ & $3.72^{\text {bed }}$ \\
\hline $\mathrm{V}_{1} \mathrm{~T}_{3}$ & $42.21^{\text {bed }}$ & $5.05^{\mathrm{b}}$ & $4.47^{\mathrm{b}}$ & $3.29^{\mathrm{d}}$ \\
\hline $\mathrm{V}_{1} \mathrm{~T}_{4}$ & $42.09^{\text {bed }}$ & $4.09^{\mathrm{de}}$ & $3.93^{\mathrm{d}}$ & $3.65^{\mathrm{cd}}$ \\
\hline $\mathrm{V}_{2} \mathrm{~T}_{0}$ & $37.94^{\mathrm{de}}$ & $3.88^{\mathrm{e}}$ & $3.75^{\mathrm{d}}$ & $4.22^{\mathrm{a}}$ \\
\hline $\mathrm{V}_{2} \mathrm{~T}_{1}$ & $46.18^{\mathrm{ab}}$ & $4.24^{\mathrm{d}}$ & $4.18^{\text {bed }}$ & $3.45^{\mathrm{cd}}$ \\
\hline $\mathrm{V}_{2} \mathrm{~T}_{2}$ & $43.25^{\mathrm{abc}}$ & $4.45^{\mathrm{c}}$ & $4.39^{\mathrm{be}}$ & $3.77^{\mathrm{be}}$ \\
\hline $\mathrm{V}_{2} \mathrm{~T}_{3}$ & $44.46^{\mathrm{abc}}$ & $4.21^{\mathrm{d}}$ & $4.08^{\mathrm{c}}$ & $4.15^{\mathrm{ab}}$ \\
\hline $\mathrm{V}_{2} \mathrm{~T}_{4}$ & $40.81^{\mathrm{cd}}$ & $4.96^{\mathrm{be}}$ & $4.54^{\mathrm{b}}$ & $4.27^{\mathrm{a}}$ \\
\hline Level of Significance & $* *$ & $*$ & $*$ & $* *$ \\
\hline $\mathrm{CV} \%$ & 5.82 & 2.30 & 2.53 & 6.45 \\
\hline
\end{tabular}

Note: Means in a column followed by the same letters or without letter are not significantly different at $1 \%$ and $5 \%$ level by DMRT; where ** - Significant at $1 \%$ level; * - Significant at 5\% level.
Effect of varieties and plant development regulators on the yield contributing characteristics of tomato Number of fruits per cluster: Significant variation was found between the varieties for fruits per cluster (Table 5). The number of fruits per cluster varied from 2.34 to 3.01 . The maximum (3.01) fruits were produced per cluster in BARI Hybrid Tomato-4 which was statistically different from BARI Tomato-4 (2.43). 4-CPA at $40 \mathrm{ppm}$ concentration (3.15) gave the highest number of fruits per cluster among the treatments but the minimum (2.11) number of fruits per cluster was found in non-PGR treatment. The remaining plant development regulator application, GA3 at $20 \mathrm{ppm}$ (2.81), 4-CPA at $20 \mathrm{ppm}$ (2.70) and $\mathrm{GA}_{3}$ at $10 \mathrm{ppm}$ (2.59) concentrations were given a little bit higher result over non-PGR application. Exogenous plant development regulator application of fruits per cluster. increased fruit set percent which resulted from number 
The number of fruits per cluster did not show any significant variation by the combined effect of varieties and plant development regulator (Table 6). It was observed that the highest (3.41) number of fruits per cluster was obtained in $\mathrm{V}_{2} \mathrm{~T}_{2}$ which was statistically similar to $\mathrm{V}_{2} \mathrm{~T}_{4}$ (3.20), $\mathrm{V}_{2} \mathrm{~T}_{1}$ (3.10), $\mathrm{V}_{2} \mathrm{~T}_{3}$ (2.97), $\mathrm{V}_{2} \mathrm{~T}_{0}$ (2.33), $\mathrm{V}_{2} \mathrm{~T}_{0}$ (2.30) and $\mathrm{V}_{1} \mathrm{~T}_{3}$ (2.21). The treatment $\mathrm{V}_{1} \mathrm{~T}_{0}$ gave the lowest (1.90) number of fruits per cluster followed by the remaining combinations that gave statistically similar results.

The Number of fruits per plant: Significant variation was observed in number of fruits per plant between two beat tolerant varieties (Table 5). The number of fruits per plant ranged from 8.35 to 12.70 . The higher (12.70) number of fruits per plant was produced in BARI Hybrid Tomato-4 and the minimum (8.35) number of fruits per plant was obtained in BARI Tomato-4. Phookan et al. (1990) conducted an experiment to evaluate 29 varieties of tomato in relation to eight different development and yield attributing parameters under plastic house conditions during the summer season and found fruit number ranging from 2.67 to 70.00 which are good in agreement with the result of the present study. The results also have a similarity to the findings of Ahmad (2002).

Table 5: Main effects of varieties and plant yield regulators on the yield contributing characteristics of tomato.

\begin{tabular}{|c|c|c|c|c|}
\hline Treatment & $\begin{array}{l}\text { Number of } \\
\text { fruits/cluster }\end{array}$ & $\begin{array}{l}\text { Number of } \\
\text { fruits/plant }\end{array}$ & $\begin{array}{l}\text { Number of } \\
\text { fruits/plot }\end{array}$ & $\begin{array}{c}\text { Days to } \\
1^{\text {st }} \text { harvest }\end{array}$ \\
\hline \multicolumn{5}{|c|}{ Variety } \\
\hline$V_{1}$ & $2.34^{\mathrm{b}}$ & $8.35^{b}$ & $60.80^{b}$ & 61.60 \\
\hline $\mathbf{V}_{2}$ & $3.01^{\mathrm{a}}$ & $12.70^{\mathrm{a}}$ & $105.47^{\mathrm{a}}$ & 60.27 \\
\hline Level of significance & ** & $* *$ & $* *$ & NS \\
\hline \multicolumn{5}{|c|}{ Plant development regulator } \\
\hline $\mathbf{T}_{\mathbf{0}}$ & $2.11^{\mathrm{c}}$ & $5.77^{\mathrm{e}}$ & $43.16^{d}$ & 60.50 \\
\hline$T_{1}$ & $2.70^{b}$ & $10.63^{c}$ & $96.83^{b}$ & 61.00 \\
\hline $\mathbf{T}_{2}$ & $3.15^{\mathrm{a}}$ & $16.45^{\mathrm{a}}$ & $115.83^{a}$ & 60.50 \\
\hline $\mathbf{T}_{3}$ & $2.59^{b}$ & $7.18^{d}$ & $64.83^{c}$ & 61.33 \\
\hline $\mathbf{T}_{4}$ & $2.81^{b}$ & $12.57^{\mathrm{b}}$ & $95.00^{\mathrm{b}}$ & 61.33 \\
\hline Level of significance & ** & ** & $* *$ & NS \\
\hline CV (\%) & 9.04 & 9.18 & 5.81 & 6.34 \\
\hline
\end{tabular}

Note: Means in a column followed by the same letters or without letter are not significantly different at $1 \%$ and $5 \%$ level by DMRT; where ** - Significant at $1 \%$ level; NS -Non-Significant.

The plant development regulator influenced significantly on the number of fruits per plant (Table 5) and produced the higher (16.45) number of fruits per plant than that of non-PGR treatment (5.77). The highest numbers (16.45) of fruits per plant were 1 obtained with spraying of 4-CPA plant development regulator at the concentration of $40 \mathrm{ppm}$ and the second highest (12.57) numbers of fruits per plant were found by $\mathrm{GA}_{3}$ at the concentration of $20 \mathrm{ppm}$. The third (10.63) and fourth (7.18) highest numbers of fruits per plant was obtained from spraying 4-CPA and $\mathrm{GA}_{3}$ at the concentrations of $20 \mathrm{ppm}$ and $10 \mathrm{ppm}$ respectively. There are also reports that numbers of fruits per plant were increased under polytunnel with tomatotone application (AVRDC, 2005). The combined effect on the number of fruits per plant was significantly Afferent (Table 6). The treatment $\mathrm{V}_{2} \mathrm{~T}_{2}$ gave the highest (22.48) number of fonts over the treatment $\mathrm{V}_{1} \mathrm{~T}_{0}(5.65)$ followed by the rest which were statistically different from each other except treatment $\mathrm{V}_{2} \mathrm{~T}_{4}$ (18.17) and $\mathrm{V}_{1} \mathrm{~T}_{1}$ (11.81) was the second and third highest number of fruits per plant respectively, because the treatment $\mathrm{V}_{2} \mathrm{~T}_{3}(7.50), \mathrm{V}_{1} \mathrm{~T}_{3}$ (6.86), $\mathrm{V}_{1} \mathrm{~T}_{4}$ (6.97),, $\mathrm{V}_{2} \mathrm{~T}_{0}$ (5.90) gave the statistically similar results. The findings of AVRDC (1997) demand that fruits per plant were increased under polytunnel conditions with hormonal treatment.

Number of fruits per plot: Significant variation was observed between two varieties of BARI Hybrid Tomato- 4 and BARI Tomato- 4 in case of number of fruits per plot (Table 5). The higher (105.47) number of fruits per plot were counted in BARI Hybrid 
Tomato-4 than that of BARI Tomato-4 (60.80). The plant development regulator influenced significantly the number of fruits per plot (Table 5). The highest (115.83) number of fruits per plot was obtained due to spraying of 4-CPA at $40 \mathrm{ppm}$ concentration over nonplant development regulator treatment (43.16). $\mathrm{GA}_{3}$ (95.00) and 4-CPA (96.83) both at $20 \mathrm{ppm}$ concentrations gave the second-highest number of fruits per plot. The number of fruits per plot showed significant variation by the combined effect of varieties and plant development regulator (Table 6). The highest (144.00) number fruits per plot ware counted in treatment combination of $\mathrm{V}_{2} \mathrm{~T}_{2}$ and the lowest in $\mathrm{V}_{1} \mathrm{~T}_{0}$ (39.00). The second-highest treatment $\mathrm{V}_{2} \mathrm{~T}_{4}$ (129.33) was statistically dissimilar with other treatment combinations of $\mathrm{V}_{2} \mathrm{~T}_{1}$ (117.67), $\mathrm{V}_{1} \mathrm{~T}_{2}$ (87.67) and $\mathrm{V}_{2} \mathrm{~T}_{3}(89.00)$.

Table 6: Effects of varieties and plant development regulators on the yield contributing features of tomato.

\begin{tabular}{|c|c|c|c|}
\hline Treatment & $\begin{array}{c}\text { Number of } \\
\text { fruits/cluster }\end{array}$ & $\begin{array}{c}\text { Number of } \\
\text { fruits/plant }\end{array}$ & $\begin{array}{c}\text { Number of } \\
\text { fruits/plot }\end{array}$ \\
\hline $\mathbf{V}_{\mathbf{1}} \mathbf{T}_{\mathbf{0}}$ & $1.90^{\mathrm{d}}$ & $5.65^{\mathrm{f}}$ & $39.00^{\mathrm{g}}$ \\
\hline $\mathbf{V}_{\mathbf{1}} \mathbf{T}_{\mathbf{1}}$ & $2.30^{\mathrm{cd}}$ & $11.81^{\mathrm{c}}$ & $76.00^{\mathrm{e}}$ \\
\hline $\mathbf{V}_{\mathbf{1}} \mathbf{T}_{\mathbf{2}}$ & $2.90^{\mathrm{b}}$ & $10.43^{\mathrm{cd}}$ & $87.67^{\mathrm{d}}$ \\
\hline $\mathbf{V}_{\mathbf{1}} \mathbf{T}_{\mathbf{3}}$ & $2.21^{\mathrm{cd}}$ & $6.86^{\text {ef }}$ & $40.67^{\mathrm{g}}$ \\
\hline $\mathbf{V}_{\mathbf{1}} \mathbf{T}_{\mathbf{4}}$ & $2.41^{\mathrm{c}}$ & $6.97^{\text {ef }}$ & $60.67^{\mathrm{f}}$ \\
\hline $\mathbf{V}_{\mathbf{2}} \mathbf{T}_{\mathbf{0}}$ & $2.33^{\mathrm{cd}}$ & $5.90^{\text {ef }}$ & $47.33^{\mathrm{g}}$ \\
\hline $\mathbf{V}_{\mathbf{2}} \mathbf{T}_{\mathbf{1}}$ & $3.10^{\mathrm{ab}}$ & $9.46^{\mathrm{d}}$ & $117.67^{\mathrm{c}}$ \\
\hline $\mathbf{V}_{\mathbf{2}} \mathbf{T}_{\mathbf{2}}$ & $3.41^{\mathrm{a}}$ & $22.48^{\mathrm{a}}$ & $144.00^{\mathrm{a}}$ \\
\hline $\mathbf{V}_{\mathbf{2}} \mathbf{T}_{\mathbf{3}}$ & $2.97^{\mathrm{ab}}$ & $7.50^{\mathrm{e}}$ & $89.00^{\mathrm{d}}$ \\
\hline $\mathbf{V}_{\mathbf{2}} \mathbf{T}_{\mathbf{4}}$ & $3.20^{\mathrm{ab}}$ & $18.17^{\mathrm{b}}$ & $129.33^{\mathrm{b}}$ \\
\hline Level of Significance & $\mathrm{NS}$ & $* *$ & $* *$ \\
\hline $\mathbf{C V}_{\mathbf{V}}$ & 9.04 & $9.18^{\mathrm{b}}$ & $5.81^{\mathrm{b}}$ \\
\hline
\end{tabular}

Note: Means in a column followed by the same letters or without letter are not significantly different at $1 \%$ and $5 \%$ level by DMRT; where ** - Significant at $1 \%$ level; NS -Non-Significant.

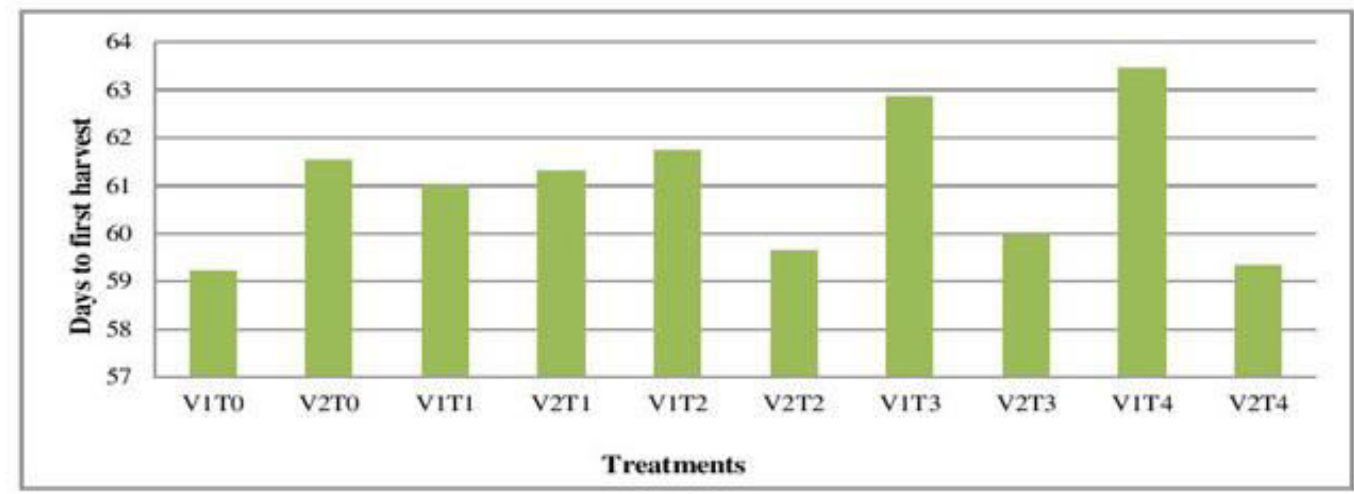

Fig 3: Combined effect of varieties and plant development regulators at the time of first harvesting.

Days to first harvest: There was no significant variation between the two varieties of tomato in the case of days to first harvest (Fig 4). BARI Hybrid Tomato-4 required minimum days (60.27) to harvesting the mature fruits which ware statistically similar to BARI Tomato-4 (61.00). The interaction effect of varieties and plant development regulators also could not perform any effect on days to first harvesting and they were statistically similar.
Individual fruit weight: There had no considerable variation observed on the individual fruit weight between two varieties (Table 7). The individual fruit weight of BARI Hybrid Tomato-4 was $39.20 \mathrm{~g}$ which is statistically similar to the variety of BARI Tomato-4 (38.02 g). Weaver and Timm, (1988) observed that at night temperature of $14^{\circ} \mathrm{C}$, tomato fruit set three times higher than the size as obtained at $26^{\circ} \mathrm{C}$. The temperature range of the present was $24.50^{\circ} \mathrm{C}$ to 
$33.25^{\circ} \mathrm{C}$. Ahmad (2002) also found the range of individual fruit weight from $5.25 \mathrm{~g}$ to $43.38 \mathrm{~g}$ among 25 heat-tolerant varieties which supports the findings of the present study. The highest $(42.53 \mathrm{~g})$ individual fruit weight was observed to spraying of 4- CPA at 20 ppm concentration and the minimum (35.75 g) was measured in non-PGR treatment (Table 7). The second highest (40.25 g) average individual fruit weight was counted by plant development regulator

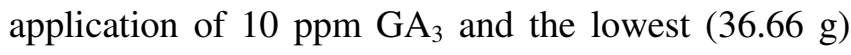
one was 4-CPA hormone at $40 \mathrm{ppm}$ concentration. Generally, average fruit weight increased 10 to $40 \%$ by the plant development regulator treatment (AVRDC, 2005).

Table 7: Main effects of varieties and plant development regulators on the yield and yield attributes of tomato.

\begin{tabular}{|c|c|c|c|c|}
\hline Treatment & Individual fruit weight (g) & Yield/plant (g) & Yield/plot (kg) & Yield (t/ha) \\
\hline \multicolumn{5}{|c|}{ Variety } \\
\hline $\mathbf{V}_{1}$ & 38.02 & $300.27^{b}$ & $7.55^{b}$ & $24.95^{b}$ \\
\hline $\mathbf{V}_{2}$ & 39.20 & $460.02^{a}$ & $11.02^{\mathrm{a}}$ & $37.75^{\mathrm{a}}$ \\
\hline Level of significance & NS & ** & *** & $* *$ \\
\hline \multicolumn{5}{|c|}{ Plant growth regulator } \\
\hline $\mathbf{T}_{\mathbf{0}}$ & $35.75^{\mathrm{e}}$ & $262.77^{\mathrm{e}}$ & $6.44^{\mathrm{e}}$ & $21.45^{\mathrm{e}}$ \\
\hline $\mathrm{T}_{1}$ & $42.53^{\mathrm{a}}$ & $402.81^{c}$ & $9.66^{c}$ & $32.19^{c}$ \\
\hline $\mathbf{T}_{2}$ & $36.66^{d}$ & $476.90^{\mathrm{a}}$ & $11.81^{\mathrm{a}}$ & $39.39^{\mathrm{a}}$ \\
\hline $\mathbf{T}_{3}$ & $40.25^{b}$ & $317.88^{d}$ & $7.97^{d}$ & $26.00^{d}$ \\
\hline $\mathbf{T}_{4}$ & $38.76^{c}$ & $440.41^{b}$ & $10.57^{b}$ & $35.20 \mathrm{~b}$ \\
\hline Level of significance & *** & *** & *** & NS \\
\hline CV (\%) & 9.04 & 9.18 & 5.81 & 6.34 \\
\hline
\end{tabular}

Note: Means in a column followed by the same letters or without letter are not significantly different at $1 \%$ and $5 \%$ level by DMRT; where ** - Significant at $1 \%$ level; NS - Non-Significant.

Significant differences were provided by the combined treatment for the character of individual fruit weight (Table 8). It was observed that the highest $(45.30 \mathrm{~g})$ individual fruit weight in gram was produced by the treatment $\mathrm{V}_{1} \mathrm{~T}_{1}$. The second highest $(43.45 \mathrm{~g})$ individual fruit weight was measured in $\mathrm{V}_{1} \mathrm{~T}_{4}$ which is statistically similar to $\mathrm{V}_{1} \mathrm{~T}_{3}(41.71 \mathrm{~g})$ treatment. Nonplant development regulator treatment combination, $\mathrm{V}_{1} \mathrm{~T}_{0}$ and $\mathrm{V}_{2} \mathrm{~T}_{0}$ gave the lowest individual fruit weight among the total plant development regulator treatment combinations which was $30.20 \mathrm{~g}$ and $35.00 \mathrm{~g}$ respectively. But the lowest average individual fruit weight was counted from $V_{1} T_{2}(29.55 \mathrm{~g})$.

\section{Effect of varieties and plant development} regulators on the yield of tomato Fruit yield per plant: There was a momentous effect of varieties on fruit yield per plant which ranged from 300.27 to $460.02 \mathrm{~g}$ per plant (Table 7). The higher $(460.04 \mathrm{~g})$ fruit yield high obtained in BARI Hybrid Tomato-4 which was statistically different from BARI Toamto-4 (300.27). Baki \& Stomuel (1993) conducted as an experiment on heat-tolerant tomato under hightemperature conditions $\left(39^{\circ} \mathrm{C}\right.$ day $/ 28^{\circ} \mathrm{C}$ night $)$ and reported that the yield of tomato varied depending on the level of heat tolerance of the varieties. The findings of Ahmad (2002) also support the results of this trait. It was revealed from the observations that the plant development regulator has a great effect on the fruit yield per plant. The plant development regulator treatment (4- CPA at the rate of $40 \mathrm{ppm}$ concentration) provided significantly higher (476.90 g) fruit yield per plant over non-plant development regulator treatment which produced on an average $262.77 \mathrm{~g}$ fruit yield per plant (Table 7). The second highest $(440.41 \mathrm{~g})$ fruit yield per plant was obtained due to the application of $\mathrm{GA}_{3}$ at the 20-ppm concentration which gave a little bit higher result than that of 4-CPA at the 20-ppm concentration (402.81 g). The findings of AVRDC (1997) also demand that fruit yield per plant increased under polytunnel conditions with plant development regulator treatment.

The combined effect on fruit yield per plant was significant among the treatment combinations (Table 8). It was observed that the highest $(621.68 \mathrm{~g})$ fruit yield per plant was obtained in $\mathrm{V}_{2} \mathrm{~T}_{2}$ which was statistically different from other treatment 
combinations. Except $\mathrm{V}_{2} \mathrm{~T}_{4}(575.21 \mathrm{~g})$ and $\mathrm{V}_{2} \mathrm{~T}_{1}$ $(482.85 \mathrm{~g})$, all other hormonal combinations were given statistically similar results. The treatment combination $\mathrm{V}_{1} \mathrm{~T}_{0}$ produced the lowest $(241.84 \mathrm{~g})$ fruit yield per plant followed by $\mathrm{V}_{1} \mathrm{~T}_{1}(322.77 \mathrm{~g}), \mathrm{V}_{1} \mathrm{~T}_{2}$ (332.11 g), $\mathrm{V}_{1} \mathrm{~T}_{3}(299.00 \mathrm{~g}), \mathrm{V}_{1} \mathrm{~T}_{4}(305.51 \mathrm{~g})$ and $\mathrm{V}_{2} \mathrm{~T}_{0}$ $(283.71 \mathrm{~g})$ and these were statistically similar to each other.

Fruit yield per plot: Remarkable variation was found between the two heat-tolerant varieties on yield per plot which ranged from $7.55 \mathrm{~kg}$ to $11.02 \mathrm{~kg}$ per plot (Table 7). The higher fruit yield $(11.02 \mathrm{~kg})$ was found from BARI Hybrid Tomato-4 which was statistically different from BARI Tomato-4 $(7.55 \mathrm{~kg})$. Picken (1984) conducted an experiment that high day (above $32^{\circ} \mathrm{C}$ ) and night (above $21^{\circ} \mathrm{C}$ ) temperature was reported as limiting fruit-set and yield due to an impaired complex of physiological process in the pistil, which results in floral or fruit abscission and yield of tomato differed depending on the level of heat tolerance of the hybrids. Findings of Ahmad (2002) also supported the results of this trait.

Significantly higher fruit yield per plot was observed due to the plant development regulator application over non-plant development regulator treatment (Table 7). In the case of the plant development regulator treatment, 4-CPA at $40 \mathrm{ppm}$ concentration, the highest $(11.81 \mathrm{~kg})$ fruit yield per plot was obtained where non-plant development regulator treatment $\left(\mathrm{T}_{0}\right)$ produced $6.44 \mathrm{~kg}$ fruits per plot. The second highest $(10.57 \mathrm{~kg})$ fruit yield per plot was recorded due to the application of $\mathrm{GA}_{3}$ at $20 \mathrm{ppm}$ concentration which is a little bit higher than the application of 4-CPA at 20 ppm concentration $(9.66 \mathrm{~kg})$. A significant difference was found by the combined effect of variety and plant development regulator in case of fruit yield per plot (Table 8). It was observed that the highest $(15.23 \mathrm{~kg})$ fruit yield per plot was produced by the treatment combination of $\mathrm{V}_{2} \mathrm{~T}_{2}$ over the treatment combinations of $\mathrm{V}_{1} \mathrm{~T}_{0}(6.17 \mathrm{~kg})$ and $\mathrm{V}_{2} \mathrm{~T}_{0}(6.70 \mathrm{~kg})$ which were statistically similar to each other and the second one was $\mathrm{V}_{2} \mathrm{~T}_{4}$ which produced $13.57 \mathrm{~kg}$ fruits per plot. The treatment combinations $\mathrm{V}_{1} \mathrm{~T}_{1}(7.80 \mathrm{~kg}), \mathrm{V}_{1} \mathrm{~T}_{2}(8.40$ $\mathrm{kg}), \mathrm{V}_{1} \mathrm{~T}_{3}(7.83 \mathrm{~kg}), \mathrm{V}_{1} \mathrm{~T}_{4}(7.57 \mathrm{~kg}), \mathrm{V}_{2} \mathrm{~T}_{3}(8.12 \mathrm{~kg})$ were statistically similar to each other.

Yield (t/ha): Significant variation was observed between the two heat-tolerant tomato varieties (Table 7) in respect of yield (t/ha). BARI Hybrid Tomato-4 gave higher fruit yield (36.75 t/ha) and the lower fruit yield 24.95 t/ha was obtained in BARI Tomato-4. An experiment was conducted with two heat-tolerant varieties (BINA Tomato-2 and BINA Tomato-3) to study the yield performance at three locations (Magura, Comilla and Khulna) during the summer season in 1997 (BINA, 1998). It was observed that BINA Tomato-2 produced higher fruit yield at Magura (38 t/ha) and Khulna (17 t/ha), while BINA Tomato-3 gave higher yield (29t/ha) at Comilla. However, mean fruit yield from three locations showed that the variety of BINA Tomato-2 produced higher fruit yield than BINA Tomato-3. The result of this experiment supports the findings of the present study.

Table 8: Combined effect of varieties and plant yield regulators on the yield and yield attributes of tomato.

\begin{tabular}{|c|c|c|c|c|}
\hline Treatment & Individual fruit weight (g) & Yield/ plant (g) & Yield/plot (kg) & Yield (t/ha) \\
\hline $\mathbf{V}_{\mathbf{1}} \mathbf{T}_{\mathbf{0}}$ & $30.20^{\mathrm{e}}$ & $241.84^{\mathrm{f}}$ & $6.17^{\mathrm{e}}$ & $20.57^{\mathrm{f}}$ \\
\hline $\mathbf{V}_{\mathbf{1}} \mathbf{T}_{\mathbf{1}}$ & $45.30^{\mathrm{a}}$ & $322.77^{\mathrm{de}}$ & $7.80^{\mathrm{d}}$ & $26.00^{\mathrm{de}}$ \\
\hline $\mathbf{V}_{\mathbf{1}} \mathbf{T}_{\mathbf{2}}$ & $29.55^{\mathrm{f}}$ & $332.11^{\mathrm{d}}$ & $8.40^{\mathrm{d}}$ & $28.00^{\mathrm{d}}$ \\
\hline $\mathbf{V}_{\mathbf{1}} \mathbf{T}_{\mathbf{3}}$ & $41.71^{\mathrm{bc}}$ & $299.00^{\mathrm{de}}$ & $7.83^{\mathrm{d}}$ & $24.94^{\mathrm{e}}$ \\
\hline $\mathbf{V}_{\mathbf{1}} \mathbf{T}_{\mathbf{4}}$ & $43.45^{\mathrm{b}}$ & $305.61^{\mathrm{de}}$ & $7.57^{\mathrm{d}}$ & $25.22^{\mathrm{e}}$ \\
\hline $\mathbf{V}_{\mathbf{2}} \mathbf{T}_{\mathbf{0}}$ & $35.00^{\mathrm{d}}$ & $283.71^{\mathrm{e}}$ & $6.70^{\mathrm{e}}$ & $22.33 \mathrm{f}^{\mathrm{f}}$ \\
\hline $\mathbf{V}_{\mathbf{2}} \mathbf{T}_{\mathbf{1}}$ & $38.71^{\mathrm{bcd}}$ & $482.85^{\mathrm{c}}$ & $11.52^{\mathrm{c}}$ & $38.39^{\mathrm{c}}$ \\
\hline $\mathbf{V}_{\mathbf{2}} \mathbf{T}_{\mathbf{2}}$ & $31.67^{\mathrm{de}}$ & $621.68^{\mathrm{a}}$ & $15.23^{\mathrm{a}}$ & $50.79^{\mathrm{a}}$ \\
\hline $\mathbf{V}_{\mathbf{2}} \mathbf{T}_{\mathbf{3}}$ & $37.65^{\mathrm{cd}}$ & $336.76^{\mathrm{d}}$ & $8.12^{\mathrm{d}}$ & $27.05^{\mathrm{de}}$ \\
\hline $\mathbf{V}_{\mathbf{2}} \mathbf{T}_{\mathbf{4}}$ & $39.98^{\mathrm{c}}$ & $575.21^{\mathrm{b}}$ & $13.57^{\mathrm{b}}$ & $45.18^{\mathrm{b}}$ \\
\hline${ }^{*}$ & $6.26^{*}$ & & ${ }^{* *}$ & ${ }^{* *}$ \\
\hline Level of Significance $_{\mathbf{C V \%}}$ & & 6.35 & 5.20 & 4.70 \\
\hline
\end{tabular}

Note: Means in a column followed by the same letters or without letter are not significantly different at $1 \%$ and $5 \%$ level by DMRT; where ** - Significant at $1 \%$ level; NS - Non-Significant. 
Plant development regulator application significantly influenced fruit yield (t/ha) over non-plant development regulator treatment (Table 7). The highest (39.39 t/ha) fruit yield per hectare was obtained from the application of 4-CPA at $40 \mathrm{ppm}$ concentration and the lowest $(21.45 \mathrm{t} / \mathrm{ha})$ fruit yield was found in non-PGR treatment. The second highest $(35.20 \mathrm{t} / \mathrm{ha})$ yield was found due to the application of
$\mathrm{GA}_{3}$ at $20 \mathrm{ppm}$ concentration which was statistically different from other plant development regulator treatments of 4-CPA (32.19 t/ha) and $\mathrm{GA}_{3}(26.00 \mathrm{t} / \mathrm{ha})$ at $20 \mathrm{ppm}$ and $10 \mathrm{ppm}$ concentrations respectively. Tomatotone appears highly efficient for yield enhancement of good F, combinations (AVRDC, 1990a).

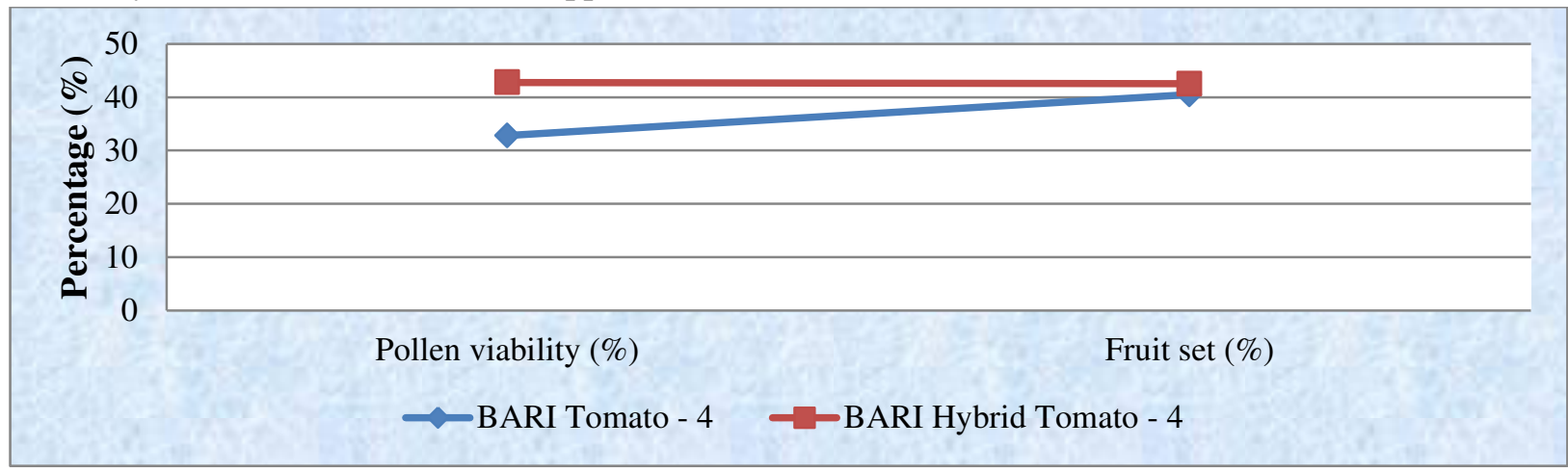

Fig 4: Comparison between the two varieties according to their pollen viability percentage and fruit set percentage.

The findings of AVRDC (1997) also demand that fruit yield per hectare increased under polytunnel conditions with plant development regulator treatment. The combined effect of varieties and plant development regulator on the yield of tomato per hectare has shown a significant variation (Table 8). It was observed that the highest (50.79 $\mathrm{t} / \mathrm{ha}$ ) fruit yield per hectare was found from the treatment combination of $\mathrm{V}_{2} \mathrm{~T}_{2}$ and $\mathrm{V}_{2} \mathrm{~T}_{4}(45.18 \mathrm{t} / \mathrm{ha}$ ) gave the second-highest yield per hectare among the other treatment combinations. The lowest (20.57 t/ha) yield was found from $\mathrm{V}_{1} \mathrm{~T}_{0}$.

Relationship between pollen viability percent and fruit set of two varieties: A positive linear relationship was observed between viability percent and fruit set percent. The equation was $\mathrm{y}=33.69+$
$0.206 \mathrm{x}$ and the value of the coefficient of determination $\left(\mathrm{R}^{2}=1.000\right)$ gave a good fit and that the fitted regression line had a significant regression coefficient. Fruit set percent increased with the increase of pollen viability percent (Fig $\mathbf{5}$ ).

\section{Relationship between pollen viability percent and} yield of two tomato varieties: When the yield of tomato per plant was regressed against pollen viability percent, a positive linear relationship was observed between them. The equation was $y=-224.54+16.01 x$ and the value of the coefficient of determination $\left(\mathrm{R}^{2}=\right.$ 1.000) gave a good fit and that the fitted regression line had a significant regression coefficient. The regression line indicated that yield per plant depends on pollen viability percent (Fig 6).

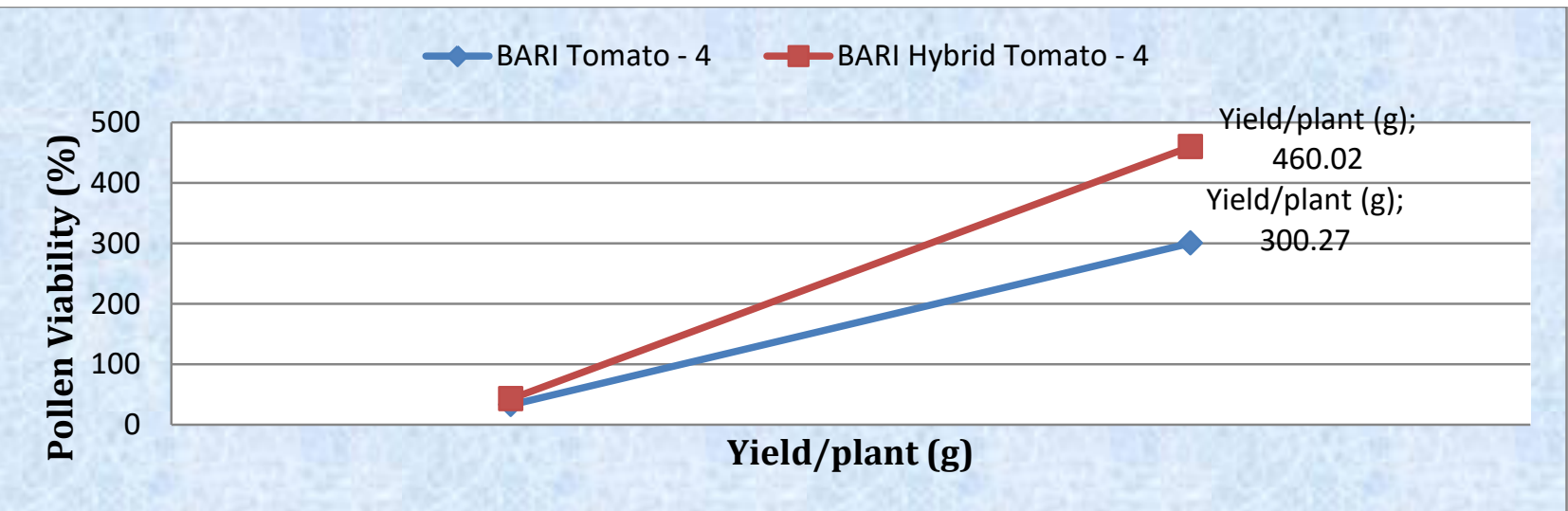

Fig 5: Comparison between the two varieties according to their pollen viability percentage and yield per plant in gram. 


\section{CONCLUSION}

The following conclusions have been made on the basis of findings of the present investigation that BARI Hybrid Tomato-4 and BARI Tomato- 4 are two common heat tolerant varieties which have shown wide range of variability on yield and its component characters. BARI Hybrid Tomato-4 performed better as it produced higher percentage of fruit set, average individual fruit weight, fruit length, fruit diameter, yield per plant as well as yield per hectare. For its high pollen viability, it showed higher fruit set under the hot-humid summer conditions of Bangladesh. Better performance was observed under the plant development regulator application of 4-CPA at 40 ppm concentration in respect of fruit set percent, number of fruits per cluster, number of fruits per plant as well as yield per plant, BARI Hybrid Tomato-4 with application of $40 \mathrm{ppm}$ 4-CPA performed the best in terms of fruit set percentage, fruits per cluster, number of fruits per plant, yield per plant and yield per hectare.

\section{ACKNOWLEDGEMENT}

Authors would like to thank Bangladesh Agriculture Research Institute (BARI) for providing all types of facilities to perform this study.

\section{CONFLICTS OF INTEREST}

The authors declared no potential conflicts of the interest with respect to the research, authorship and/or publication of this research study.

\section{REFERENCE}

1. Ahmad, S., (2002). Genetics of fruit set and related traits in tomato under hot humid conditions. Ph.D. Thesis BSMRAU. pp. 44-180

2. Anonymous, (1998). Developed vegetables varieties and technologies. Olericulture division. HRC, BARI, Joydcbpur, Gaztpurpp. 25-38

3. Anonymous, (1995). Agro-climatological data Agromet Division, Bangladesh Meteorological Department, Joydebpur, Gazipur. pp. 35-65

4. AVRDC, (1990a). Progress Report. AVRDC, Shanhua, Taiwan, pp. 19-54

5. AVRDC, (1990b). Progress Report. Asian Vegetables Research and Development Center, Shanhua, Taiwan, pp. 352-358

6. AVRDC, (1997). Progress Report. Asian Vegetables Research and Development Center, Shanhua, Taiwan, p. 447
7. AVRDC, (2005). Progress Report. Asian Vegetables Research and Development Center, Shanhua, Taiwan, pp. 124-140

8. Baki, A. A., and Stomuel, J.R., (1993). Pollen viability and fruit set of tomato genotypes under optimum and high-temperature regimes. Hort Science. 30(1): 115-117

9. BINA, (1998). New varieties of summer tomato, BINA Tomato-2 and BINAS Tomato-3 (Folder in Bengali). Bangladesh Institute of Nuclear Agriculture, Mymensingh

10. Bodo R.T., (1991). Comparison of different pollen viability assays to evaluate pollen fertility of potato diploids. Eu. phytica. 56: 143-148

11. Gomez K.A.and Gomez A.A., (1984). Statistical procedures for Agricultural Research. John Willey and Sons. Inc. New Tork. pp. 67-78

12. Kuo, C. G.; Chen, B. W.; Chou, M. H.; Tsai, C. C. and Tsay, J. S. (1979). Tomato fruit set at high temperature. In: Cowel R. (ed.) Proc. $1^{\text {st }}$ Intl. Symp. Tropical tomato. Asian Vegetable Research and Development Center, Shanhua, Taiwan. 94 - 108.

13. Nothmann, J., (1997). Varietal response of different tomato cultivars to plant growth regulator treatments. ISHS Acta Horticulturae, 137: Growth regulators, XXI IHC

14. Phookan D.B., Talukdar P., Shadeque A., and Chakravarty B.K., (1990). Genetic variability and heritability in tomato (Lycopersicon esculentum Mill.) genotypes during the summer season under plastic house condition. Indian J. Agric. 68(6): 304-306

15. Picken, A.J.F., (1984). A review of pollination and fruit set in tomato (Lycopersicon esculentum Mill.). Horticulture Science, 59: 1-13

16. Rama M.K. and Kalloo G., (1989). Hightemperature tolerance in tomato: Evaluation of genotypes. Veg. Sci. 16(2): 156-167

17. Ramin A.A., (1998). Effect of 4-CPA on fruit set in tomato under low temperatures in the field. Department of Horticulture, College of Agriculture, Shahid Kamrun University, Ahwaz, Iran. P 205-210

18. Rylski, I., Gan-More, S., Nahir, D. and Abraham, H., (1984). Improved open-field tomato yield with pulsed air jacket shaker installed on a tractor, Hassedeh, 64, 688-91

19. Shaheed S.M., (1984). Soil of Bangladesh: General Soil Types. Soil Resources Development 
Institute (SRDI), Dhaka, Bangladesh. p. 3

20. Shahen MZ, Mahmud S, Rony MH, Sohana SN, Imran MAS, Uddin ME and Alam MS. (2019). Effect of Antibiotic Susceptibility and Inhibitory Activity for the Control of Growth and Survival of Microorganisms of Extracts of Calendula officinalis. Eur. J. Med. Health Sci., 1(1), 1-9. https://doi.org/10.34104/ejmhs.019

21. Stevens M.A., (1979). Breeding tomatoes for processing. In: Tropical tomato. R. Cowell (ed.). Asian Vegetable Research and Development Center (AVRDC), Shanhua, Taiwan, p. 290

22. Stevens, M.A. and Rudich, J., (1978). Genetic potential for overcoming physiological limitations on adaptability, yield, and quality in the tomato. Horticultural Science, 13: 673-678

23. Villareal R.L. and Lai S.H., (1979). Development of heat-tolerant tomato varieties in the topics. In: $1^{\text {st }}$ Intl. Symp. Tropical Tomato, W. R. Cowel (ed.). AVRDC, Shanhua, Taiwan, p. 290

24. Weaver, M.L. and Timm, H., (1988). Influence of temperature and plant water status on pollen viability in Tomato. Journal of American Society for Horticultural Science, 113(1): 31-35

25. Zahedi SM, Ansari NA (2012). Comparison in Quantity Characters (Flowering and fruit set) of ten (10) selected tomato (Solanum lycopersicum L.) Genotypes under subtropical climate conditions (Ahvaz). Intl. Res. J. App. Basic Sci., 3(6): 1192-1197.

Citation: Hossain SM, Sarker C, and Mahmud S. (2019). Effect of plant growth regulator on the growth and high yield of heat tolerant tomato variety (Lycopersicon esculentum Mill). Am. J. Pure Appl. Sci., 1(5), 30-43. https://doi.org/10.34104/ajpab.019.0193043 (c) 